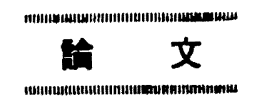

UDC $669.046 .58: 532.613 .4: 669.141 .15-404$

\title{
溶融鉄合金と $\mathrm{CaO}-\mathrm{Al}_{2} \mathrm{O}_{3}$ スラグとの間の 界面張力の測定について
}

\author{
向井 楠宏**.加藤 時夫*** . 坂尾 弘****
}

\section{On the Determination of Interfacial Tension between Liquid Iron Alloy and $\mathrm{CaO}-\mathrm{Al}_{2} \mathrm{O}_{3}$ Slag}

Kusuhiro MukaI, Tokio Kato, and Hiroshi SAKao

\begin{abstract}
Synopsis:
An improved method for measurement of interfacial tension between liquid iron alloy and liquid slag has been developed. The method is based on simultaneous determination both surface tension of liquid iron alloy $\sigma_{\mathrm{mg}}$, which is measured by use of large drop method, and contact angle of liquid slag droplet on the liquid iron alloy. The interfacial tension ' $\sigma_{\mathrm{m} \mathrm{s}} \stackrel{\circ}{\mathrm{s}}$ ' between $\mathrm{CaO}-\mathrm{Al}_{2} \mathrm{O}_{3}$ slag and liquid iron alloy was determined at $1570^{\circ} \mathrm{C}$ by the method within 0.5 second after contacting the two liquids. Results obtained are as follows: (1) Oxygen dissolved in liquid iron brings about drastic decrement of $\sigma_{\mathrm{ms}}^{\circ}$, while both carbon and chromium in liquid iron lowers slightly $\sigma_{\mathrm{m} \mathrm{s}}^{\circ}$. (2) Both decrement of $\sigma_{\mathrm{m} \mathrm{s}}^{\circ}$ and that of $\sigma_{\mathrm{mg}}$ by addition of one of the elements mentioned above into liquid iron are nearly equal to one another, and also both decrement of $\sigma_{\mathrm{m}}^{\circ}$ and that of surface tension of $\mathrm{CaO}-\mathrm{Al}_{2} \mathrm{O}_{3}-\mathrm{SiO}_{2}$ slag $\sigma_{\mathrm{sg}}$ by addition of $\mathrm{SiO}_{2}$ component into the slag are nearly equal to one another. (3) Main cause of the interfacial tension character will be induced by independent contributions both of $\sigma_{\mathrm{mg}}$ and $\sigma_{\mathrm{sg}}$ respectively, while interaction between the slag and the iron alloy may play a minor role in the interfacial tension character. (4) Work of adhesion $W_{a}$ between the slag and the iron alloy within 0.5 second after contacting the two liquids keeps constant value even when only one of the two liquids makes change in composition.
\end{abstract}

(Received Mar. 9, 1972)

\section{1. 緒}

言

溶融鉄合金と溶融スラグ間の界面張力の測定には ( a ) 溶融鉄合金表面上のスラグ滴の形状より求める方法と, (b)スラグ中の溶融鉄合金滴の形状より求める方法の二 つがおもに用いられている.（a）の方法によつて求めら れる界面張力と，（b)の方法によつて求められる界面張 力は, 測定条件が異なるため測定値の比較, 解釈あるい は,それらの測定値を治金現象の解析に用いる場合には, それぞれの方法によつて求められた測定値の区別を明確 にして取扱うことが必要である. 従来この区別が必ずし も明確になされてきたとはいえない。

本研究は (a)の方法を用いて溶融鉄合金と溶融スラグ 間の界面張力を測定し，（a）の方法によつて求められた 界面張力という見地から，得られた結果の若干の解釈を 試みたものである. その場合, 従来の（a）の方法に基本 的な改良を加えることによつて, 測定精度の向上をはか
つた，測定系は，製銑，製鋼に関係の深い. $\mathrm{CaO}-\mathrm{Al}_{2} \mathrm{O}_{3}$ 系スラグと溶鉄を基本系として，スラグ側に $\mathrm{SiO}_{2}$, 溶 鉄側に非金属元素であり，製銑，製鋼反応の主成分であ る酸素, 炭素, および金属元素のクロムを添加した系を 選えだ.

\section{2. 実 験 方 法}

\section{$2 \cdot 1$ 界面張力測定法}

溶融鉄合金上のスラグ滴は Fig. 1 に示すようなレン ズ状を呈する．溶融鉄合金および，スラグのそれぞれの 表面張力 $\sigma_{\mathrm{mg}}, \sigma_{\mathrm{sg}}$ が既知の場合, 界面張力 $\sigma_{\mathrm{ms}}$ は, 接触角 $\alpha$ を測定することにより, 力学的平衡から(1)式

* 昭和 46 年 1 月鉄鋼基礎共同研究会第 5 分科会 にて発表

昭和 47 年 3 月 9 日受付

** 九州工業大学 工博

****大同製鋼 (株)

**** 名古屋大学工学部 工博 


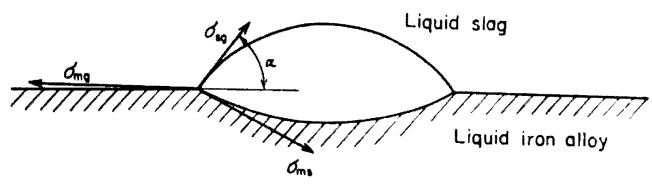

Fig. 1. Shape of liquid slag droplet on liquid iron alloy.

によつて求められる.

$$
\sigma_{\mathrm{ms}^{2}}=\sigma_{\mathrm{mg}}{ }^{2}+\sigma_{\mathrm{sg}}{ }^{2}-2 \sigma_{\mathrm{mg}} \sigma_{\mathrm{sg}} \cos \alpha
$$

(1) 式を用いて $\sigma_{\mathrm{ms}}$ を算出する場合, 従来の測定法 では， $\sigma_{\mathrm{sg}}, \sigma_{\mathrm{mg}}$ とも別個に測定した值を用いて行なう. $\sigma_{\mathrm{sg}}$ は $\sigma_{\mathrm{mg}}$ に比較して絶対值が小さく, 測定中に試料 の污染などによつて $\sigma_{\mathrm{sg}}$ の值に変化が生じても， $\sigma_{\mathrm{ms}}$ の 測定値の相対誤差に大きく寄与するものではない，それ ゆ光， $\sigma_{\mathrm{sg}}$ には別個に測定した值を用いても誤差の大き な原因にならない。これに対して $\sigma_{\mathrm{mg}}$ は，絶対值が大 きく，また，溶融鉄合金に容易に溶解する酸素，硫黄な ぞの微量の存在により著しく変化し， $\sigma_{\mathrm{mg}}$ に別個に測 定した值を用いることは, 結果として, 界面張力の值の 信頼度を低下させることになる．ゆえに， $\sigma_{\mathrm{mg}}$ と $\alpha$ を 同時に測定しうる方法が望ましい.

本研究ではそのため，まず表面がほほ平面と見なしう るような大滴の溶融鉄合金を用いて，その表面張力 $\sigma_{\mathrm{mg}}$ を測定後，直ちにその鉄合金の上にスラグを滴下し，両 者の間の接触角 $\alpha$ を光学的に測定する方法を考案し, 界 面張力の測定を行なつた.

溶融鉄合金の表面張力 $\sigma_{\mathrm{mg}}$ の測定には，静滴法を用 いる場合, BASHFORTH，ADAMS の式と表1)を用いるが， 滴の表面が水平とみなせるような大滴（Fig. 2) に対し ては, BASHFORTH, ADAMS の表"の範囲を越えるため, PORTER ${ }^{2)}$ による近似式(2)を用いる.

$$
\beta^{2}=\frac{1}{2} h^{2}-0 \cdot 3047 h^{2} \cdot \frac{h}{r}\left(1-4 \frac{h^{2}}{r^{2}}\right)
$$

ここで, $\beta^{2}=\sigma / g \cdot \rho, h$ は滴の最大水平面から頂点まで の高さ, $r$ は最大水平面の半径, $g$ は重力加速度, $\rho$ は 測定物質の密度， $\sigma$ は表面張力である.

大滴を平板にのせた場合は, 計算の前提となる滴の回 転対称からのずれが大きくなる．本実験では，滴が回転 対称を保ちうるように真円度が良好で，滴を保持する端 部に凹凸がない, 内径 $45 \mathrm{~mm}$, 樑さ $4 \mathrm{~mm}$ の半溶融ア ルラナ $\left(99 \%\right.$ 以上 $\left.\mathrm{Al}_{2} \mathrm{O}_{3}\right)$ 製平皿を作製し，所定位置に 水平にセットする方法を採つた.

(2)式の $h$ を求めるために, カメラの撮影倍率が必要 であるが，これは，真球度が良好な鋼球を用い，それを溶 融鉄合金の大滴を置く同じ位置にセットし，この状態で

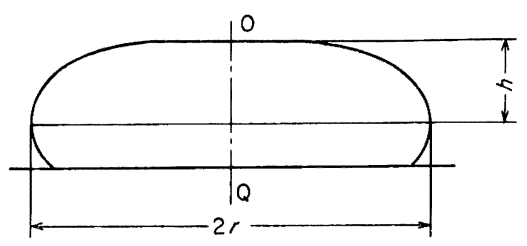

Fig. 2. Sketch of sessile drop of liquid iron alloy showing elements of measurements.

撮影したネガフィルム上の鋼球の像と実物の大きさとの 比から求めた. (2)式の $r, h$ の測定は, 撮影したネガ フィルムを工場顕微鏡（ $\frac{1}{1000} \mathrm{~mm}$ まで読取り可能）を 用いて行なつた。

接触角 $\alpha$ の則定は，前述の工場顕微鏡に装着してある 分度器で行ない, 左右の 測定值の 平均值からの偏差は $\pm 1^{\circ}$ 以内であつた。

\section{2 試 料}

\section{$2 \cdot 2 \cdot 1 \quad \mathrm{CaO}-\mathrm{Al}_{2} \mathrm{O}_{3}$ 系スラグ}

$\mathrm{CaO}$ としては, 試薬特級の $\mathrm{CaCO}_{3}$ を高アルミナ質 るつほ内で, 大気中, $1100^{\circ} \mathrm{C}, 120 \mathrm{~min}$ 加熱分解した ものを用いた. $\mathrm{Al}_{2} \mathrm{O}_{3}$ としては, メルク社製ガスクロマ トグラフ分析用アルミナを， $\mathrm{SiO}_{2}$ としては，試薬特級 無水ケイ酸を用いた.

粉末状の $\mathrm{CaO}, \mathrm{Al}_{2} \mathrm{O}_{3}$ を重量比 1: 1 となるように調 合し乳鉢で十分混合後，分析用黒鉛るつぼ内で約 1550 ${ }^{\circ} \mathrm{C}$ で $30 \mathrm{~min}$ 溶融し，その間黒鉛棒を用いて十分㩭拌 したものを鉄鋳型に注入急冷した・これを mother slag として， $\mathrm{SiO}_{2}$ を含有するスラグの作成は，この mother slag に適当量の $\mathrm{SiO}_{2}$ を添加し, 上記の操作を繰返して 所定の組成の酸化物を得た。

\section{$2 \cdot 2 \cdot 2$ 鉄合金試料}

電解鉄 $(99.9 \% \mathrm{Fe}$ 以上) を高酸素含有試料の場合は マグネシアるつほ (MG 1, MgO 96\%), 低酸素の場合 はアルミナるつほ（ $\mathrm{AD}, \mathrm{Al}_{2} \mathrm{O}_{3} 99 \%$ 以上) 中で, アル ゴンまたはアルゴン $+10 \%$ 水素雾囲気にて, 高周波誘 導加熱により溶解し， $1600^{\circ} \mathrm{C}$ に $60 \mathrm{~min}$ 保持した後, 炭素あるいはクロムを含む場合には，それぞれ炭素飽和 鉄, 電解クロムを所定組成になるよう投入する．投入後 さらに, $1600^{\circ} \mathrm{C}, 30 \mathrm{~min}$ 保持した後急冷して試料とす る.

試料中の酸素, 炭素はそれぞれ電量滴定法による国際 電気KK製クーロマチック O, クーロマチック Cを用い て分析し, クロムは過硫酸アンモニウム酸化容量法によ つて分析した.

\section{3 実験装粗}

実験装置は，ガス精製装置，真空槽，モリブデン加熱 


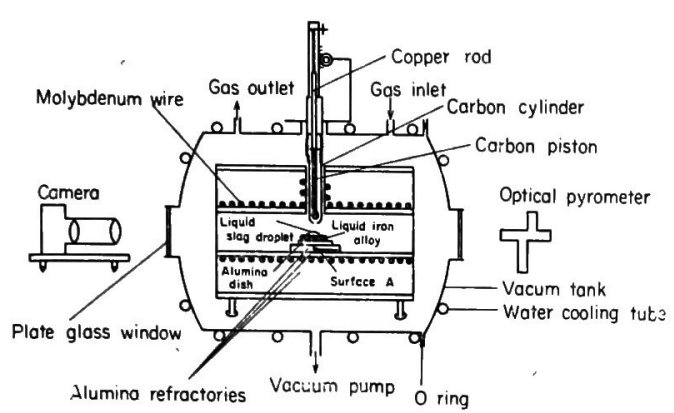

Fig. 3. Sketch of experimental apparatus.

炉，光学測定装置からなつている. その概略を Fig. 3 に示す.

モモリブデン線の酸化と溶融鉄合金の酸化を防ぐため, 雾囲気として，精製アルゴン + 1〜 10\%水素の混合ガス を用いた.モリブデン炉は，4本の支持脚を介して，外 部より水平調節が可能である. 真空槽の左右両端にはガ ラス㲅があり，溶融鉄合金，スラグ滴の撮影および光高 温計による測温が可能である. 外部との連結部はOリン グによつて気密に保たれている. 加熱炉は内径 $60 \mathrm{~mm}$, 長さ $450 \mathrm{~mm}$ の市販の多孔質焼結アルミナ (TOKU-A) 製炉心管と炉心管を取巻く発泡性アルミナ耐火物からな るモリブデン線加熱炉である.

スラグ滴下装置として，分析用黒鉛製滴下管とピスト ンが真空槽の中央上部に取りつけてある. 滴下管は外部 から上下動可能な円管に固定する. 黑鉛製ピストンはネ ジで銅棒に固定され，銅棒は外部からの操作で上下動が 可能である．滴下管に粒状スラグを入れ，スラグが溶融 すれば，外部からの操作でピストンを上下させることに より，滴下管先端の穴 ( $3 \mathrm{~mm}$ 径) より滴下できるよう になつている. 表面張力 $\sigma_{\mathrm{mg}}$, 界面張力 $\sigma_{\mathrm{ms}}$ の測定の ための写真撮影はガラス空を通して $200 \mathrm{~mm}$ 望遠レンズ にベローズを装着したモータードライブカメラを用いて 行なつた.

\section{4 実験操作}

前述のアルミナ製平皿に鉄合金試料約 $140 \mathrm{~g}$ 学のせ, 炉内の所定の位置に水平にセットする. 次に粒状スラグ 約 $1.5 \mathrm{~g}$ を滴下管に入れる. その後真空槽を $10^{-3} \mathrm{~mm}$ $\mathrm{Hg}$ 程度に真空排気後, 精製したアルゴン水素混合ガス を導入する. 測定系が所定の温度に達したのち，表面張 力 $\sigma_{\mathrm{mg}}$ を測定するための写真撮影をする. その直後に, スラグ滴を滴下装置から約 $0.3 \mathrm{~g}$ 滴下し, 界面張力測定 用の写真を撮影する. 測温は光高温計により, 平血支持 台中にあけてある孔底（Fig. 3 で示すA面）の温度を測 定することにより行なつた. 測定中の温度变化は $\pm 5^{\circ} \mathrm{C}$
であつた・

\section{3. 結果と考察}

\section{$3 \cdot 1$ 測定上の問題点について}

$3 \cdot 1 \cdot 1$ 大滴法による表面張力 $\sigma_{\mathrm{mg}}$ の測定

PORTER の式2)を用いて求めた表面張力 $\sigma_{\mathrm{mg}}$ は, 後述 するように既報の文献值と誤差の範囲内でよく一致する 結果を得た. 著者はその後さらに PORTER の式)の信頼 性を確かめるために, 別の研究3) で同一の実験条件のも とで同一の溶鉄試料に対して, PORTER の式)を用いた大 滴法と, BASHFORTH, ADAMS の式と表1)用いた方法と の二つの方法から表面張力を求め, 両者は, 同一酸素濃 度の場合よく一致する結果を得た.

大滴法で注意すべきことは, 横型の炉を用いる場合, 大滴の頂部が真の頂部より低く撮影されることである. このことは，溶鉄上に浮かんでいるスラグ滴が， Photo.

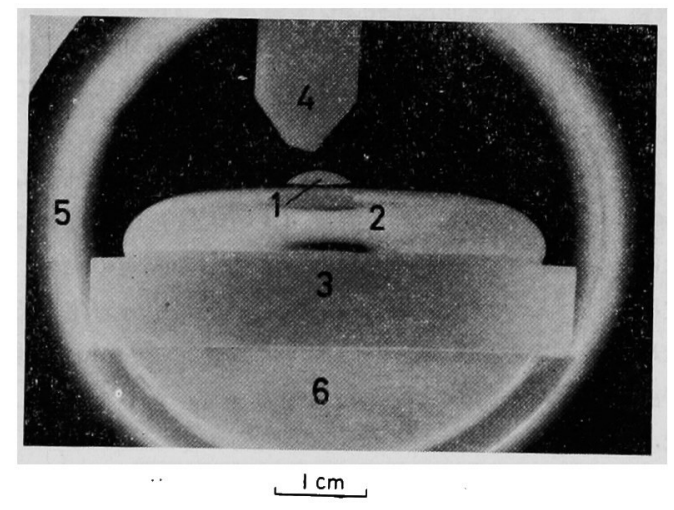

1: Slag droplet. 2: Liquid iron alloy. 3: $\mathrm{Al}_{2} \mathrm{O}_{3}$ dish.

4 : Carbon cylipder. 5 : Furnace tube. 6: Dish support.

Photo. 1. Slag droplet on the iron alloy surface without a cabon plate behind the droplet in the furnace tube.

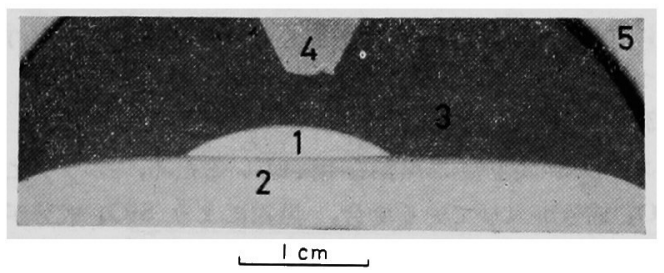

1: Slag droplet. 2 : Liquid iron alloy. 3 : Carbon plate. 4: Carbon cylinder. 5: Furnace tube.

Photo. 2. Slag droplet on the iron alloy surface with a carbon plate 3 behind the droplet in the furnace tube. The slag droplet in Photo. 1 appears to be separate from the iron surface, while the slag droplet in this photograph does not. 


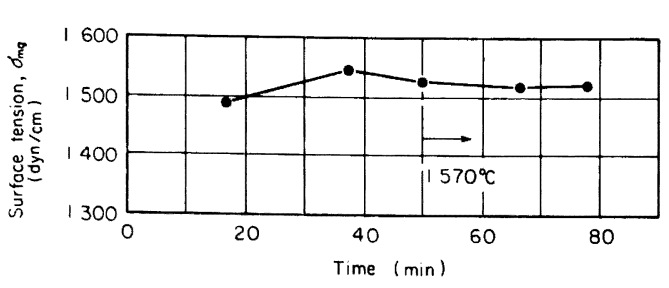

Fig. 4. Variation of surface tension of liquid pure iron with time after melting.

1 に示すように, 溶鉄面から中空に分離して浮かび上が つているようにみえることで明らかである．この原因は 大滴の頂部付近が, 背景となる炉心管の出口の暗黑部を 映している結果であると考えられる.したがつて，大滴 の背景となる暗黒部に適当な発光体をおいて正しく頂部 の位置を撮影するか，あるいはスラグ滴が浮かんでいる 状態での大滴を用いて，スラグ滴の形状を考虑に入れて 大滴の頂部を決定する方法を工夫しなければならない。 レンズ状のスラグ滴の両端の位置を大滴の頂部として求 めた結果は, 発光体として黒鉛板を大滴の背後において 撮影した結果 (Photo. 2 ) とよく一致した.

鉄試料の溶融後の, 大滴法による表面張力の測定值は, Fig. 4 に示すように, 測定温度 $\left(1570^{\circ} \mathrm{C}\right)$ に到達後は ほぼ一定值を示すが, 後に続く界面張力の測定のため, 次項に述べるかげろう現象が消滅し叔況が十分安定する ための時間を考慮して, 測定温度に到達後 $20 \mathrm{~min}$ 以後 の測定値を，溶融鉄合金の表面張力 $\sigma_{\mathrm{mg}}$ として採用し た.

\section{$3 \cdot 1 \cdot 2$ かげろう現象}

本装置の真空槽内の容積は大きく, ガスの流量が大き い場合とか，昇温中あるいは測定温度に到達後しばらく は, 槽内の対流が激しく, ガス相の温度差による光の屈 折率の差から，かげろう現象が観察された。したがつて 測定時は, ガス流量を $50 \mathrm{cc} / \mathrm{min}$ とし, 測定系を一定温 度に保持し，かげろう現象がなくなつた状態で測定を行 なつた。

\section{$3 \cdot 1 \cdot 3 \mathrm{SiO}_{2}$ の還元}

スラグの滴下管に 黒鉛を用いているため，スラグに $\mathrm{SiO}_{2}$ 成分が入つている場合，黒鉛により $\mathrm{SiO}_{2}$ 成分が 還元されるおそれがある.本実験の場合もスラグ滴の滴 下の際, 気泡が生成しているのが観察された、本実験で は，しかし $\mathrm{SiO}_{2}$ 成分の混合割合が，スラグの滴下時に おいても変化しないものとして測定値を処理した.

\section{2 接触直後の界面張力, $\sigma_{\mathrm{ms}}{ }^{\circ}$ について}

本法で求めた界面張力は，スラグ滴下後約 $0.5 \mathrm{sec}$ 以 内に測定されたものであり，これを接触直後の界面張力

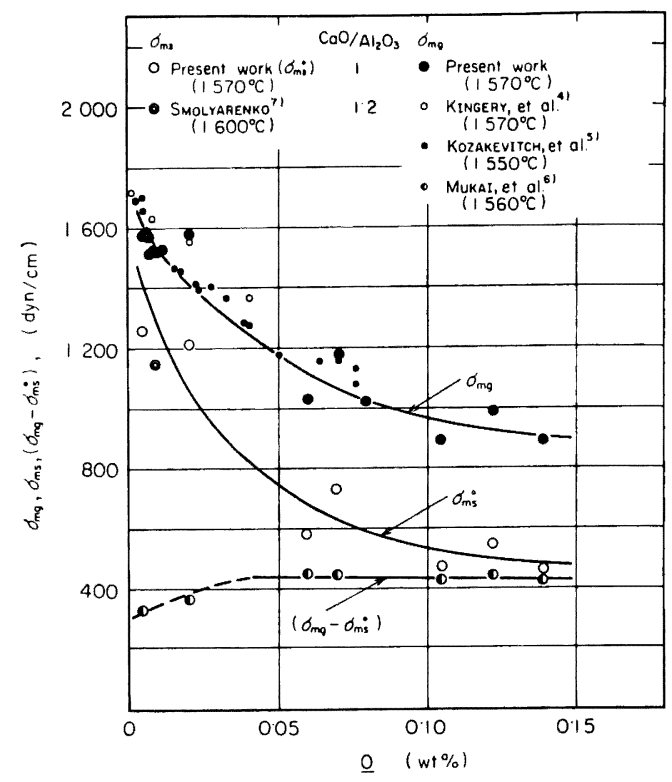

Fig. 5. Variations of $\sigma_{\mathrm{mg}}, \sigma_{\mathrm{ms}} \stackrel{\circ}{\text { and }}\left(\sigma_{\mathrm{mg}}-\sigma_{\mathrm{ms}} \stackrel{\circ}{)}\right.$ with oxygen content of liduid iron. $\sigma_{\mathrm{mg}}:$ Surface tension of liquid iron.

$\sigma_{\mathrm{ms}}:$ : Interfacial tension between liquid iron and $\mathrm{CaO}-\mathrm{Al}_{2} \mathrm{O}_{3}$ slag within 0.5 second after contacting the two liquids.

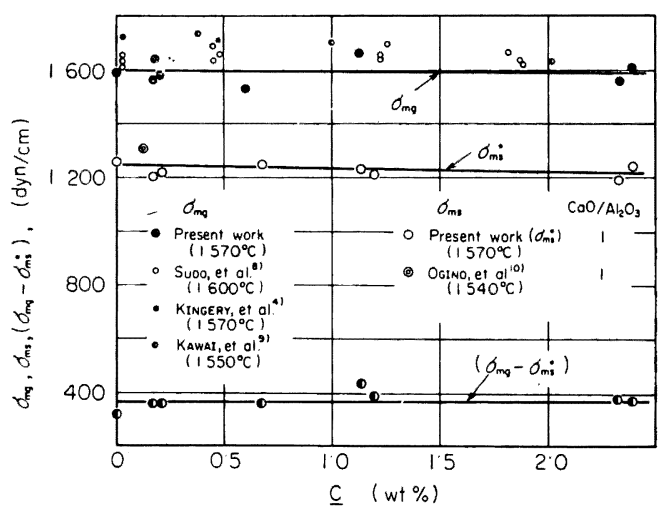

Fig. 6. Variations of $\sigma_{\mathrm{mg}}, \sigma_{\mathrm{ms}} \stackrel{\circ}{\text { and }}\left(\sigma_{\mathrm{mg}}-\sigma_{\mathrm{ms}}\right)$ with carbon content of liquid iron alloy. $\sigma_{\mathrm{mg}}$ : Surface tension of liquid iron alloy. $\sigma_{\mathrm{ms}}^{\circ}:$ Interfacial tension between liquid iron alloy and $\mathrm{CaO}-\mathrm{Al}_{2} \mathrm{O}_{3}$ slag within 0.5 second after contacting the two liquids.

' $\sigma_{\mathrm{ms}}{ }^{\circ}$ と呼ぶことにする.

まず，溶鉄側に酸素，炭素およびクロムを添加した場 合の結果を Fig. 5，6，7 に示す. 図中には大滴法で求 めた表面張力 $\sigma_{\mathrm{mg}}$ の值と他の測定者の值を同時に示し たが, Fig. 5 に示すように, Fe-O 系の場合, 測定誤差 


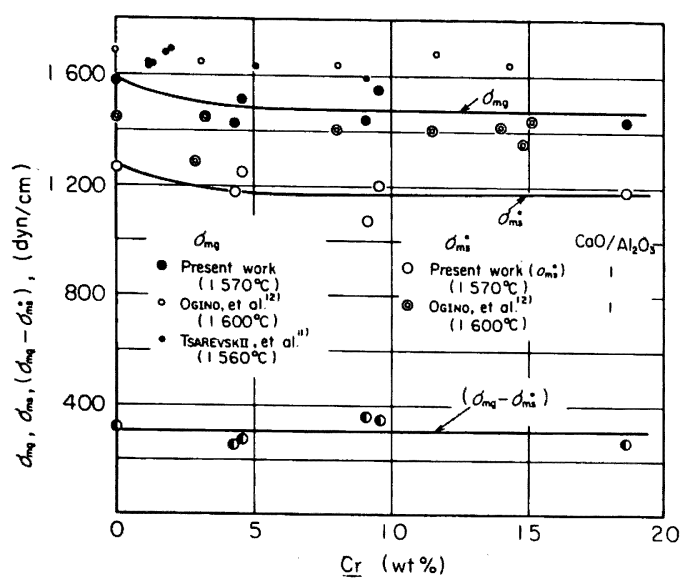

Fig. 7. Variations of $\sigma_{\mathrm{mg}}, \sigma_{\mathrm{ms}}^{\circ}$ and $\left(\sigma_{\mathrm{mg}}-\sigma_{\mathrm{ms}}\right)$ with chromium content of liquid iron alloy. $\sigma_{\mathrm{mg}}:$ Surface tension of liquid iron alloy. $\sigma_{\mathrm{ms}}^{\circ}:$ Interfacial tension between liquid iron alloy and $\mathrm{CaO}-\mathrm{Al}_{2} \mathrm{O}_{3}$ slag within 0.5 second after contacting the two liquids.

範囲内でほぼ一致している， Fe-C, $\mathrm{Fe}-\mathrm{Cr}$ 系の場合， 本測定值は他の測定者の值より低い.このおもな原因と して第一に, 表面張力の算出に使用した密度の相異が考 えられる. Fe-C 系の場合, 同一の密度を用いて, 本測 定值と他の測定者(1)8) との值を比較すると，測定誤差範 囲内で十分良好な一致を示す. $\mathrm{Fe}-\mathrm{Cr}$ の場合は他の測 定者の作用した密度の詳細な值が不明なので比較できな い. 第二の原因として，とくにクロムの場合，用いた電 解クロム中の表面活性な不純物元素および溶鉄試料中に 含まれる酸素の影響が考えられる.このような事実から も, 他の測定者の值, あるいは別個の実験での測定值 $\sigma_{\mathrm{mg}}$ を $\sigma_{\mathrm{ms}}{ }^{\circ}$ の算出にそのまま使用するのは疑問であ ることが指摘できる. 本測定法は，このような溶鉄側の 成分の変化による $\sigma_{\mathrm{ms}}{ }^{\circ}$ の変化をしらべるのに適した 方法である.なお，溶鉄の密度には， $\mathrm{Fe}-\mathrm{O}, \mathrm{Fe}-\mathrm{C}, \mathrm{Fe}$ -Cr の各系に対してそれぞれ LUCAS ${ }^{13)}$ (純鉄の密度)， LUCAS $^{14)}$ ，BENEDICKS $5^{15)}$ の值を LUCAS ${ }^{13)}$ の純鉄の值に 平行移動した值を用いた。

$\sigma_{\mathrm{ms}}{ }^{\circ}$ は酸素含有量の増加によつて著しく減少するが, 炭素, クロムの場合, 減少割合は, 酸素の場合に比して 著しく小さい，ここで注目すべきことは，酸素, 炭素, クロムのすべての場合において， $\left(\sigma_{\mathrm{mg}}-\sigma_{\mathrm{ms}}{ }^{\circ}\right)$ の值が測 定組成範囲内でほぼ一定であること, すなわち $\sigma_{\mathrm{ms}}{ }^{\circ}$ の 减少割合が， $\sigma_{\mathrm{mg}}$ の減少割合と, 測定組成範囲内におい て，ほほ等しくなつていることである、ただし， Fe-O 系において低酸素浱度側では, 測定誤差の範囲内である
が，( $\left(\sigma_{\mathrm{mg}}-\sigma_{\mathrm{ms}}{ }^{\circ}\right)$ が低くなつている．この原因として第 一に，スラグ滴の接触角の減少速度の相違が考えられ る. すなわち, スラグ滴下後の接触角の滅少速度は，溶 鉄の酸素濃度の増加とともに大きくなるため, 約 $0.5 \mathrm{sec}$ 経過後の界面張力の測定值は, 高酸素浱度側で小さめの 測定值が得られる結果, $\left(\sigma_{\mathrm{mg}}-\sigma_{\mathrm{ms}}{ }^{\circ}\right)$ が低酸素浱度側で みかけ上低くなることが考えられる. 第二に，この低酸 素浱度領域は, 溶鉄表面の過剩酸素濃度が, 急激に変化 するところであり，この影響が何らかの形で作用してい るものと考えられる.したがつて酸素とか硫黄のような 強い表面活性元素については, 低濃度領域を含めて $\left(\sigma_{\mathrm{mg}}\right.$ $\left.-\sigma_{\mathrm{ms}}^{\circ}\right)$ が一定になるかどうかについて, より詳細な検 討が必要である.

つぎにスラグ側に $\mathrm{SiO}_{2}$ 成分を添加した場合の測定結 果を Fig. 8 に示す. $\sigma_{\mathrm{sg}}$ の值は郡司ら ${ }^{16)}$ の測定值を用 いた. $\mathrm{SiO}_{2}$ 含有量の増加に対する $\sigma_{\mathrm{ms}}{ }^{\circ}$ と $\sigma_{\mathrm{sg}}$ の変化 の割合は, $\mathrm{SiO}_{2}$ 含有量が 0 5\% の間を除いては, ほぼ 等しいとみなせる. $\mathrm{SiO}_{2}$ 含有量が 0 〜 $5 \%$ の範囲を除 いたのは， $\sigma_{\mathrm{sg}}$ がその範囲では $\mathrm{SiO}_{2}$ 含有量の増加とと もに増加しているのに， $\sigma_{\mathrm{ms}}{ }^{\circ}$ は減少しているからであ る. しかし, この組成領域で $\sigma_{\mathrm{sg}}$ が $\mathrm{SiO}_{2}$ 含有量の増加 とともに減少するという SMOLYARENKO ら", BOBKOVA ら の) の測定結果があり，この組成領域での $\sigma_{\mathrm{sg}}$ のいつそ うの研究を待たないことには，現段階でこの領域につい ての結論を下すことはできない.

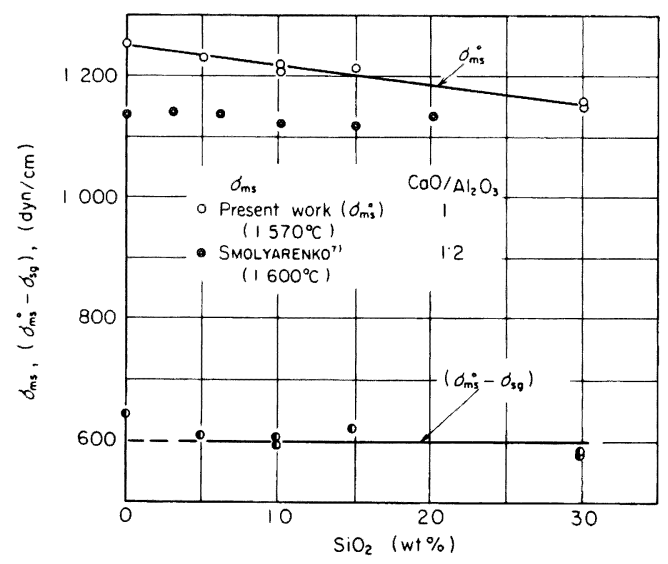

Fig. 8. Variations of $\sigma_{\mathrm{sg}}, \sigma_{\mathrm{ms}} \stackrel{\circ}{\text { and }}\left(\sigma_{\mathrm{ms}}-\sigma_{\mathrm{sg}}\right)$ with $\mathrm{SiO}_{2}$ content of $\mathrm{CaO}-\mathrm{Al}_{2} \mathrm{O}_{3}-\mathrm{SiO}_{2}$ slag. $\sigma_{\text {sg }}:$ Surface tension of $\mathrm{CaO}-\mathrm{Al}_{2} \mathrm{O}_{3}-\mathrm{SiO}_{2}$ slag. $\sigma_{\mathrm{m} \mathrm{s}}:$ Interfacial tension between liquid iron and $\mathrm{CaO}-\mathrm{Al}_{2} \mathrm{O}_{3}-\mathrm{SiO}_{2}$ slag within 0.5 second after contacting the two liquids. 
$\sigma_{\mathrm{mg}}$ が一定であれば， $\left(\sigma_{\mathrm{ms}}{ }^{\circ}-\sigma_{\mathrm{sg}}\right)$ がスラグ組成によ らないという関係は, 溶融ニッケルと $\mathrm{CaO}-\mathrm{SiO}_{2}$ 采ス

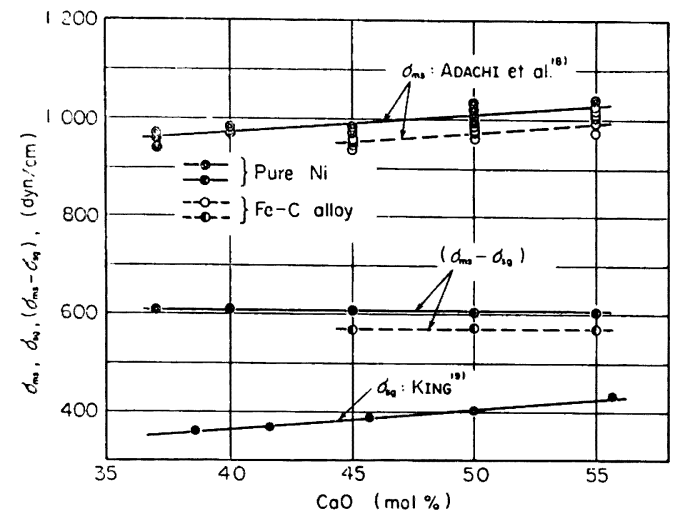

Fig. 9. Variations of $\left.\sigma_{\mathrm{sg}}{ }^{19)}, \sigma_{\mathrm{ms}^{18}}\right)$ and $\left(\sigma_{\mathrm{ms}}{ }^{18}\right)$ $\left.\sigma_{\mathrm{sg}}{ }^{19}\right)$ with $\mathrm{SiO}_{2}$ content of $\mathrm{CaO}-\mathrm{SiO}_{2}$ slag. $\sigma_{\mathrm{sg}}$ : Surface tension of $\mathrm{CaO}-\mathrm{SiO}_{2}$ slag. $\sigma_{\mathrm{ms}}$ : Interfacial tension between liquid metal and $\mathrm{CaO}-\mathrm{SiO}_{2}$ slag immediately after contacting the two liquids.

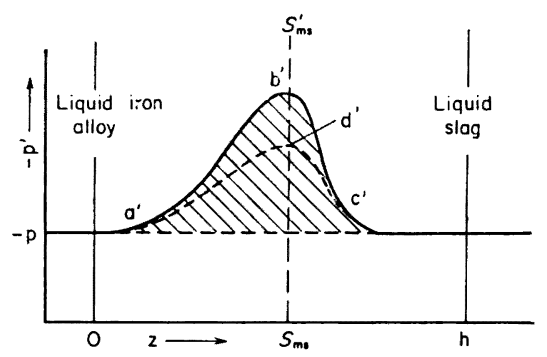

(c) (a)

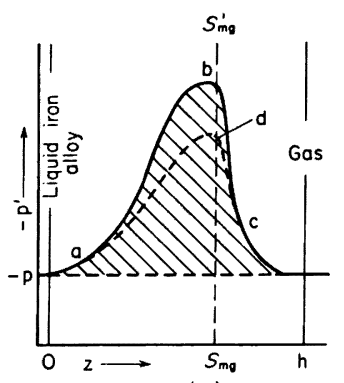

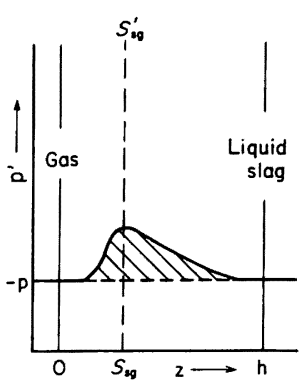

(b)
$S^{\prime}$ : Dividing surface. $p$ and $\mathrm{p}^{\prime}$ : Pressure normal and tangential to any thin film of liquid parallel to the surface or the interface respectively. $z$ : The space coordinate measured normal to the surface or the interface.

Fig. 10. Illustrating the equation(3). The ruled area of (a), (b) and (c) represents surface tension of liquid iron alloy, $\sigma_{\mathrm{mg}}$, surface tension of liquid slag, $\sigma_{\mathrm{sg}}$, and interfacial tension, between the alloy and the slag, $\sigma_{\mathrm{ms}}$ respectively.
ラグおよび $\mathrm{Fe}-\mathrm{C}(4 \cdot 3 \%)$ 合金と $\mathrm{CaO}-\mathrm{SiO}_{2}$ 系スラグ に対する足立ら ${ }^{18)}$ の界面張力の測定結果に対しても成立 していることがわかる（Fig. 9). 足立ら ${ }^{18)}$ の測定した 界面張力はすべて，（a）の方法で求めたものであり， $\sigma_{\mathrm{ms}}{ }^{\circ}$ とみなせるものである.

$\mathrm{BAKKER}^{20)}$ の取扱いをもとにすれば，表面張力 $\sigma$ は次 式で表わされる.

$$
\sigma=\int_{0}^{h}\left(P-P^{\prime}\right) d z
$$

ここでPは，表面に平行なうすい層に垂直な方向の圧 力, $P^{\prime}$ はその層に平行な方向の圧力, $z$ は表面に垂直 な方向の座標， 0 と $h$ はそれぞれ表面をはさんで，一方 の側の均一相と他方の側の均一相のなかにある.

したがつて，接触前の溶融鉄合金およびスラグの表面 張力は Fig. 10, ( a ), (b)の斜線の部分の面積で示すこと ができる．溶鉄中への不純物元素の添加によつて, $\Delta \sigma_{\mathrm{mg}}$ だけ表面張力が減少した場合, 面積 abcd が $\Delta \sigma_{\mathrm{mg}}$ に
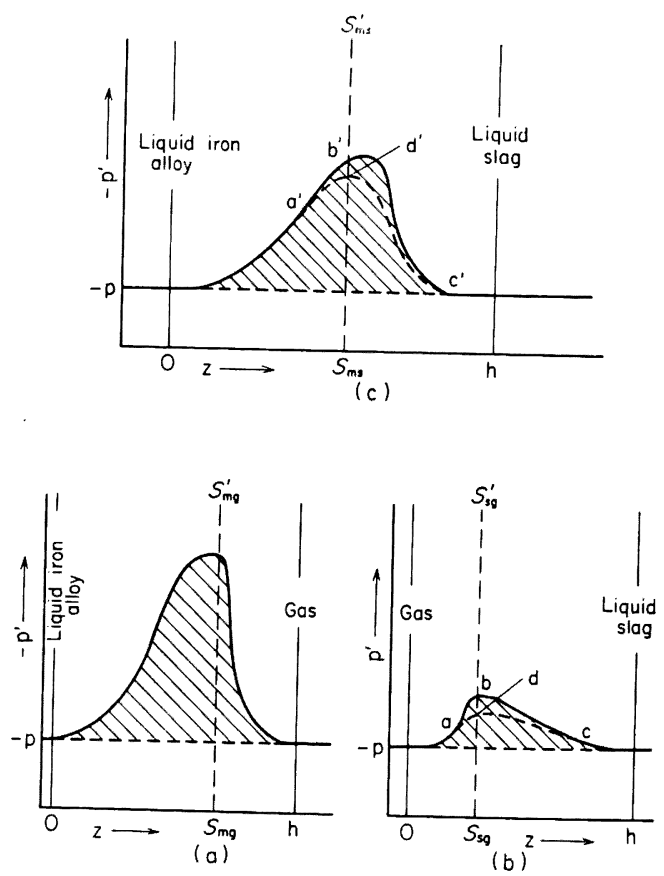

SS': Dividing surface. $p$ and $p^{\prime}$ : Pressure normal and tangential to any thin film of liquid parallel to the surface or the interface respectively. $z$ : The space coordinate measured normal to the surface or the interface.

Fig. 11. Illustrating the equation (3). The ruled area of (a), (b) and (c) represents surface tension of liquid iron alloy, $\sigma_{\mathrm{mg}}$, surface tension of liquid slag, $\sigma_{\mathrm{sg}}$, and interfacial tension between the alloy and the slag, $\sigma_{\mathrm{ms}}$ respectively. 
相当する.

接触直後の 界面張力 $\sigma_{\mathrm{ms}}{ }^{\circ}$ の測定時点において，す でに力学的平衡が成立しているものとすれば（この仮定 は本法の界面張力の測定原理のもとをなす仮定でもあ る)，BAKKER 20) の取扱いをスラグー溶鉄界面の界面張 カへ適用して, Fig. 10，（c）のように図示することが できる. 斜線部の面積が $\sigma_{\mathrm{ms}}$ ○に等しい. 溶鉄中への不 純物元素の添加によつて, $\Delta \sigma_{\mathrm{ms}}{ }^{\circ}$ だけ界面張力が 減少 した場合，面積 $\mathrm{a}^{\prime} \mathrm{b}^{\prime} \mathrm{c}^{\prime} \mathrm{d}^{\prime}$ (Fig. 10，(c)) が $\Delta_{\mathrm{ms}}{ }^{\circ}$ に相 当する.

本実験結果は, $\Delta \sigma_{\mathrm{ms}}{ }^{\circ}=\Delta \sigma_{\mathrm{mg}}$, すなわち面積 $\mathrm{abcd}=$ 面積 $a^{\prime} b^{\prime} c^{\prime} d^{\prime}$ であることを示している. 同様に，スラグ 組成が変化した場合の表面張力, 界面張力のそれぞれの 変化を $\Delta \sigma_{\mathrm{sg}}, \Delta \sigma_{\mathrm{ms}}$ ○ とすれば, $\Delta \sigma_{\mathrm{sg}}=\Delta \sigma_{\mathrm{ms}}$ ○であり, Fig. 11 で面積 $a b c d=$ 面積 $a^{\prime} b^{\prime} c^{\prime} d^{\prime}$ であることを実験 結果は示している. 溶鉄への添加元素が酸素, 炭素, ク ロムと異なる場合でもこの関係は成立する，スラグ組成 を変化させた場合についても， $\mathrm{SiO}_{2}$ 含有量の変化に対 して, $\mathrm{CaO}-\mathrm{SiO}_{2}, \mathrm{CaO}-\mathrm{Al}_{2} \mathrm{O}_{3}-\mathrm{SiO}_{2}$ 系と，異なるスラ グ系に対してもこの関係が成立する．また溶鉄に限らず 溶融ニッケルに対しても, 本関係が成立する.

以上の結果から， $\sigma_{\mathrm{ms}} \circ$ の以上のような特性は主に両 相の表面張力の寄与をそれぞれ独立に受けて生じたも のであり, 界面の遷移領域での両相の相互作用によつて 生じる寄与量は，非常に小さな割合しか占めないといえ る.したがつて面積 $a^{\prime} b^{\prime} c^{\prime} d^{\prime}$ (Fig. 10) は溶鉄成分が主 成分になつている遷移領域に大部分があり，スラグ成分 が主成分となる領域には，ほとんど存在しないと考える のが妥当である. スラグの組成が変化する場合の面積 a'b'c'd' (Fig. 11) については, その存在位置について, 面積 a'b'c'd' (Fig. 10) とまつたく逆のことがいえる.

力学的見地からすれは，界面に平行な方向の圧力 $P^{\prime}$ は, 溶融鉄合金とスラグ両相の接触直後においては, 溶 融鉄合金側の成分が異なる場合は，主に溶融鉄合金側の 僄移領域の $P^{\prime}$ が変化し，スラグ側の成分が異なる場合 は，主にスラグ側の遷移領域で $P^{\prime}$ が变化すると考えら れる.

スラグの溶融鉄合金からの分離のしやすさの尺度とし て，付着仕事 $W_{\mathrm{a}}$ ，またスラグの溶融鉄合金表面へのひ ろがりやすさの尺度として拡張係数 $S$ が用いられ，それ ぞれ次式で定義される.

$$
\begin{aligned}
& W_{\mathrm{a}}=\sigma_{\mathrm{sg}}+\sigma_{\mathrm{mg}}-\sigma_{\mathrm{ms}} \\
& S=\sigma_{\mathrm{mg}}-\sigma_{\mathrm{sg}}-\sigma_{\mathrm{ms}} \cdots
\end{aligned}
$$

本実験結果より， $\sigma_{\mathrm{sg}}$ を一定にした場合， $\left(\sigma_{\mathrm{mg}}-\sigma_{\mathrm{ms}}\right)$ は，溶融鉄合金の組成に依存せず，ほほ一定になる。し
たがつて， $W_{\mathrm{a}} ， S$ も一定になる， $\sigma_{\mathrm{mg}}$ を一定にして， スラグ組成を变化させた場合も同様に，( $\left.\sigma_{\mathrm{sg}}-\sigma_{\mathrm{ms}}\right)$ は 一定になり， $W_{\mathrm{a}}$ は一定になる.したがつて接触直後の スラグー溶融鉄合金間においては，両相のうち一方のみ の組成を変化させてもスラグの溶融鉄合金からの分蜼の しやすさは変化しないことがわかる.

\section{4. 結言}

大滴法を用いて溶融鉄合金の表面張力を測定すると同 時に溶融鉄合金表面上に浮かぶスラグ滴の接触角を測定 して, 界面張力を求める方法を開発し, 溶融鉄合金と溶 融スラグ間の接触直後 $(0.5 \mathrm{sec}$ 以内) の界面張力の測定 を行なつた. その結果,

(1) $\mathrm{CaO}-\mathrm{Al}_{2} \mathrm{O}_{3}$ スラグに対し, 溶鉄中の酸素, 炭 素, クロムの影響を調べたが, 酸素が著しく界面張力を 減少させる.

（2）（1）の場合, 酸素, 炭素, クロムのおのおのの 元素の溶鉄への添加による界面張力の減少割合は, 溶鉄 の表面張力の減少割合にほほ等しい.

（3）溶鉄成分を一定にした場合， $\mathrm{CaO}-\mathrm{Al}_{2} \mathrm{O}_{3}$ スラ グへの $\mathrm{SiO}_{2}$ 成分の添加による界面張力の隇少割合は, スラグの表面張力の減少割合にほぼ等しい.

（4）本測定で得られるような接触直後の界面張力の もつ以上のような特性は, したがつて溶融鉄合金, スラ グ両相の表面張力の寄与を独立にうけて生じたものであ り, 界面での相互作用による寄与の割合は非常に小さい と考光られる.

（5）スラグの溶融鉄合金からの分離のしやすさの尺 度としての付着仕事 $W_{\mathrm{a}}$ は, 接触直後のスラグ-溶融鉄 合金間においては，両相のうち，一方のみの組成を変え ても変化しない。

1) F. BAshforth and $S . C$. 献 to Test the Theories of Capillarity, (1883), [Cambridge Univ. Press]

2) A.W. Porter: Phil. Mag., 15 (1933), p. 163

3 ) 向井, 古河: 鉄と鋼, 57 (1971) 11, S 465

4) $W . D$. Kingery and F. A. Halden: J. Phys. Chem., 59 (1955), p. 557

5 ) P. Kozakevitch and $G$. Urbain: Memoires Sci. Rev. Met., 58 (1961), p. 517

6 ) 向井, 坂尾, 佐野: 日本金属学会誌, 31 (1967), p. 923

7; $V . D$. Cmolyarenko, A. M. Yakushev, and F. P. Edneral: Izv. VUZov, Cher. Met.,(1956) 3 , p. 36

$8)$ 須藤, 門間: 日本金属学会誌, 24 (1960), p.167

9）川合，森，石倉：鉄鋼基礎共同研究会提出資料, 
1970年 1 月

10) 荻野, 足立, 末滰, 斉藤：鉄と鋼，51 (1965), p. 1857

11) B. V. Tsarevskil and S.I. Popel: Izv. VUZov, Cher. Met., (1960) 12, p. 15

12）荻野，原，宇賀：鉄鋼基礎共同研究会資料，1971 年 1 月

13) L. D. Lucas: Compt. Rend., 250(1960), p.1850

14) L. D. Lucas: Compt. Rend., 248(1959), p. 2336

15) C. Benediks, $N$. Ericsson, and $G$. ERicsson: Arch. Eisenhüttenw., 3 (1930), p. 473
16）郡司，捻，小野：鉄鋼基礎共同研究会提出資料， 1970年 5 月

17) O.S. Bobkova and B.S. Petukhov: Izv. Akad. Nauk. SSSR, (1963), p. 212

18) 足立, 荻野，末淁：鉄と鋼，50 (1964)，p. 1838

19) T.B. KING: J. Soc. of Glars Tech., 35 (1951), p. 241

20) G. BAKKer: Handbuch der Experimentalphysik, vol. 6, ed. by $W$. WIEN and F. Harms, (1928), Chapter 15 [Akademische Verlagsgesellschaft, Leipzig] 